\title{
Łarysa Briuchowećka
}

\section{NIE ZMIENIAJAC POGLADÓW. PRZEDSTAWIANIE OKRUCIENSSTWA I ZŁA W FILMACH ANDRZEJA WAJDY}

DOI: 10.19195/0860-116X.39.6

W wielowymiarowym świecie mamy do czynienia z przejawami szlachetności i dobra, okrucieństwa i zła. Ta prawda jest tyleż banalna, co niezaprzeczalna. Na temat XX stulecia, które Robert Conquest nazwał „splądrowanym”, Mikołaj Bierdiajew, jeszcze zanim rozpoczęło się niszczenie ludzi z precyzją i pewnością automatu, postawił taką diagnozę: teoria postępu w rozwoju ludzkości doznała krachu, moralna degradacja towarzysząca osiągnięciom naukowym i technicznym przeraża, jakby postęp pokazał swoją odwrotną, mroczną stronę. Liczne próby wytłumaczenia koszmaru, jaki przeżyła ludzkość w XX stuleciu, trudno sprowadzić do ostatecznego wniosku. Jedni odwołują się do zwierzęcego okrucieństwa cechującego ontologicznie naturę człowieka, inni zaś przyczynę zła, które na niebywałą w historii skalę dosięgło ludzi, widzą w politycznych kataklizmach. Wśród mistrzów XX w., którzy to zło konsekwentnie wydobywali na powierzchnię z głębin jednostkowej psychiki i z głębin społecznych, jest Andrzej Wajda. Nie kręcił on ani filmów policyjnych, ani thrillerów czy w ogóle filmów akcji — zło, które pokazywał, było realne i poznawalne. I właśnie dlatego często zwracał się ku tragicznym czasom wojny (Pokolenie, Kanat, Popiót i diament, Korczak, Katyń) i wielkim dramatom światowej klasyki (Makbet, Mistrz i Małgorzata, Biesy, Zbrodnia i kara). Zadziwiająca jest w jego biografii twórczej stale aktywna postawa jako mistrza i badacza.

Gdy się myśli o źródłach jego nielekkiej i ofiarnej misji, przypomina się bohater filmu Andrieja Tarkowskiego Dzieciństwo Iwana, owładnięty pragnieniem ze- 
msty na wrogu za zakłócenie spokojnego życia, za śmierć najdroższego człowieka - matki. W dzieciństwie Andrzej Wajda też przeżył wstrząs w wyniku straty bliskiej osoby: jako trzynastolatek po raz ostatni widział swojego ojca-oficera, który z wieloma innymi polskimi żołnierzami trafił do radzieckiej niewoli i do domu już nie powrócił. Jak Iwan z filmu Tarkowskiego młody Wajda włączył się do walki z wrogiem, a złożywszy przysięgę żołnierza AK, wykonywał zadania łącznika w podziemiu antyhitlerowskim. Na szczęście los go ochronił. Bardzo możliwe, że przeżyta w dzieciństwie trauma dała asumpt do badania i ukazywania zła, które tak gwałtownie wtargnęło w życie jego rodziny, kraju, wielu rodaków. Zresztą rok 1939, który przerwał ustalony porządek życia, oraz tęsknota za czasami przedwojennymi pojawią się na ekranie w Lotnej, a także w o wiele późniejszej Kronice wypadków mitosnych.

Wcześnie dojrzały, Wajda wybiera sztukę jako sposób obrony dobra i walki ze złem. W jeden dzień dokonuje gwałtownego zwrotu w swoim życiu: najpierw marzył o karierze malarza, ale nie ukończywszy nauki w krakowskiej Akademii Sztuk Pięknych, porzuca myśl o malarstwie i wybiera kino, które bardziej intensywnie niż inne sztuki oddziaływa na ludzi. Przed ponad dwudziestu laty inny wielki reżyser tak samo zmienił swój wybór: Ołeksandr Dowżenko zamierzał zostać malarzem, ale pewnego letniego dnia 1926 r. opuścił Charków i udał się do wytwórni filmów w Odessie. Oba wybory, i pierwszy, i drugi, były z korzyścią dla filmu, a dokonane zostały w okresie radykalnych zmian społecznych.

Wiele już powiedziano i napisano o multiaspektowości i ogromie twórczej spuścizny Wajdy. Stworzył on czterdzieści filmów, zdobył międzynarodowe uznanie, nakręcił wiele filmów telewizyjnych i wyreżyserował liczne sztuki teatralne, które wywoływały rozmaite, pozytywne i negatywne, ale zawsze żywe reakcje publiczności i krytyki. W jego dorobku reżyserskim (filmowym i teatralnym) można odnaleźć mnóstwo różnorodności i odcieni, ale to już temat na inną wypowiedź.

Moim zadaniem jest przyjrzenie się konkretnemu aspektowi działań Mistrza. Interesuje mnie, jak w jego filmach pokazane jest zło i jego ślady, a także sąd nad nim. Ten wątek etyczny jest dzisiaj bardzo aktualny. Dlatego że zło, jakie czyniła władza radziecka przez cały okres swojego istnienia w jednym z największych krajów na świecie i poza jego granicami, nie zostało osądzone i ukarane. Inaczej niż w wypadku nazizmu hitlerowskiego. I teraz świat stoi przed recydywą tego nieukaranego zła.

W związku z tym choć pobieżnie przypomnę kilka faktów z dziejów recepcji filmów Wajdy w ZSRR. Właśnie w Moskwie w 1979 r. Andrzej Wajda za film Brzezina według opowiadania Jarosława Iwaszkiewicza zdobywa Złotą Nagrodę. Minie niewiele czasu, a Mistrz bezkompromisowo stanie po stronie „Solidarności”. Ten ruch społeczno-polityczny, podobnie jak słowo „solidarność”, po roku 1980 w Związku Radzieckim poddano tabuizacji i używano ich jako politycznego straszaka. Wajda, rzuciwszy wyzwanie opresyjnemu systemowi przyniesionemu 
do Polski „na bagnetach” radzieckich sił zbrojnych, po stłumieniu ruchu „Solidarności" był zmuszony do opuszczenia swojego kraju na kilka lat. Temu doświadczonemu reżyserowi filmowemu gościnnie otwarły drzwi kraje Europy, stwarzając warunki do pracy twórczej.

W tym czasie solidny moskiewski Кинословарь (Słownik filmowy), który ukazał się w 1986 r., Andrzeja Wajdy zignorować nie mógł, ale w notce biograficznej o nim informował: „W drugiej połowie lat 70. w szeregu filmów Wajda rozwija antysocjalistyczne tendencje (Człowiek z marmuru, 1976, Bez znieczulenia, 1978), co szczególnie wyraźnie przejawiło się w obrazie Człowiek z żelaza (1981)"1. O filmie tym, nagrodzonym Złotą Palmą w Cannes rzecz jasna nie wspomina się ani słowem. Ówcześni filmoznawcy rosyjscy podkreślają, że wśród filmowców krajów socjalistycznych Wajda był jednym z najostrzejszych krytyków stalinizmu.

Ale czas nie stoi w miejscu. Ze zmianą klimatu politycznego w ZSRR, upadkiem żelaznej kurtyny i wolnością słowa pojawiła się możliwość komunikacji z ludźmi kiedyś niewygodnymi. Z początkiem roku 1989 Andrzej Wajda przyjeżdża do Moskwy, a pobyt ten odnotowuje czasopismo „Искусство кино” (Sztuka Filmowa); w zamieszczonym w nim wywiadzie chodziło przede wszystkim o Wajdowskie ekranizacje rosyjskiej klasyki, ale opublikowano także fragmenty nowej książki Wajdy o teoretyczno-metodologicznych zasadach jego reżyserii filmowej²

Ale powróćmy do skomplikowanego dla Polski roku 1983. Na ekrany wchodzi Danton Wajdy, utwór o jednym z przywódców rewolucji francuskiej. Reżyser nasycił go aluzjami do współczesności, toteż widzowie odbierali ów obraz jako aktualną przypowieść polityczną. Przenikał go oddech śmierci, przejmująco czyhającej za szaloną energią bohatera i dramatycznie ją puentującą. W kłótni zrodzonej przez nienawiść do tych, „którzy nie z nami”, w ostrym, bezkompromisowym przeciwstawieniu Robespierre'a i Dantona - dwóch liderów rewolucji — stale narasta napięcie, a wszystko wiedzie do fatalnego finału. Jest on nie do uniknięcia, gdyż rewolucja uruchomiła już maszynę represji. $\mathrm{Z}$ historii wiemy, czym to wszystko się zakończyło, ale wiedza niezabarwiona emocjami pozostaje wyłącznie prostą konstatacją faktu, niczym więcej. Inaczej, gdy widzimy współczesnych, którzy przed obiektywem kamery wcielają się w ludzi odległych historycznych realiów i którym wierzymy. Obraz jest dynamiczny, energetyczny, dokładnie pokazuje, kto jest winien przelewowi krwi i jak ważne jest, by w rewolucyjnym porywie zachować ogólnoludzkie wartości, nie utracić humanitarnego stosunku do człowieka.

I Wojciech Pszoniak, i zarozumiały Gerard Depardieu ${ }^{3}$, i wszyscy, którzy pracowali przy tym wielkim obrazie, byli tworzywem w rękach reżysera, nieśli jego ważne posłanie. Wajda był reżyserem, który dla takiego posłannictwa potrafił dać

${ }^{1}$ Вайда Анджей, [hasło w:] Киноискусство.Энциклопедический словарь, Москва 1986.

2 А. Вайда, Кино - мое призвание, „Искусствокино” 1989, nr 2, s. 164-172.

${ }^{3}$ W książce-wywiadzie Gerard Depardieu niezbyt przychylnie wspominał o reżyserskich uwagach Wajdy; zob. G. Depardieu, Po prostu żyję! Rozmowy z Laurentem Neumannem, Kraków 2005. 
wykonawcom konieczny impuls i to niezależnie od tego, z jakimi aktorami pracował, z polskimi czy zagranicznymi. Jak działał taki impuls, pokazuje jeden przypadek z początku pracy nad spektaklem Zbrodnia i kara według Fiodora Dostojewskiego. Opiszę go słowami samego Wajdy:

Raskolnikow nienawidzi ludzi, odepchnięty i poniżony przez złych ludzi, on czasami czuje się lepszym od innych. Dlatego w napisanym przez niego artykule o zbrodni pozwala on wyjątkowym osobom przelewać krew! Myślałem przerażony o tym, jak zagra taką rolę zadowolony z siebie Radziwiłowicz? Wiedziałem, że w podobnym przypadku reżyser jest bezradny i uratować go może tylko cud. Odłożyłem próby, gdyż nie wiedziałem, na co mogę liczyć. Po tygodniu w drzwiach sali prób pojawił się nieznajomy: chudy, z zapadniętymi policzkami, niegolony przez kilka dni, o szybkich nerwowych ruchach. Podszedł do reżyserskiego stolika, położył teczkę i wyjął z niej siekierę, mamrocząc coś pod nosem: „Niech tu leży, może się przyda...”. Zamarłem ze strachu. Przede mną stał żywy Rodion Romanowicz Raskolnikow w osobie Jerzego Radziwiłowicza ${ }^{4}$.

Widać tu, że jako bodziec, jako inspiracja zadziałała niepewność reżysera i jego decyzja o „odłożeniu prób”.

Wajdę i jako człowieka, i jako świadomego swojej misji twórcę fascynował Dostojewski, który w XIX w. doskonale zdiagnozował zło rodzące się w „ideowych” głowach jemu współczesnych. „Gdyby nie Dostojewski, ja nie zostałbym Wajdą” — mówił reżyser. Rozległość oglądu i rozumienia procesów społeczno-politycznych pomogła Wajdzie — jako pierwszemu twórcy polskiego kina — bezkompromisowo i otwarcie opowiedzieć o tym, jak system stalinowski mełł proletariuszy na początku lat 1950. Obraz Człowiek z marmuru, gdzie to było pokazane, cudem dostał się na ekrany. A wystawiając na scenie Dostojewskiego, choćby Biesy, tak samo demaskował manipulację świadomością ludzi, grę na ich ambicjach, a przy tym stadne, snobistyczno-konformistyczne pragnienie, by nie stać obojętnie wobec postępowych i awangardowych poglądów oraz ruchów. Jednocześnie zaś Wajda realizował swoją misję, uważnie wystrzegając się niebezpieczeństw samoideologizacji.

Gdy w 1982 roku pracowałem w Paryżu nad Dantonem — pisał reżyser — to spotkałem się z dwoma amerykańskimi producentami, którzy w sekrecie powiedzieli mi, że Sołżenicyn, który wtedy już mieszkał w Stanach Zjednoczonych, chce, żebym sfilmował jego scenariusz Czołgi znaja prawdę. Była to historia buntu w sowieckim obozie, zdławionego przez wojska NKWD. Wyraźne, bardzo jaskrawe postaci mężczyzn i kobiet, akcja po mistrzowsku rozwijana. Producenci $[\ldots]$ przyznali, że mają pieniądze na anglojęzyczny film zrobiony w Stanach. Dla mnie miała znaczenie znajomość z Sołżenicynem, którego wcześniej nigdy nie widziałem. Przyjemne było i to, że wielki pisarz właśnie mnie wybrał na reżysera swojego pierwszego scenariusza 5 .

Wajda dziwił się, dlaczego właśnie jemu zaproponowano scenariusz filmu Czołgi znaja prawdę. Widocznie Sołżenicyn widział jego dzieła i może zrobiła na nim wra-

${ }^{4}$ А. Вайда, Театр сумління Достоєвського, [w:] А. Вайда, Кіно і решта світу, Київ 2004, s. $183-185$.

${ }^{5}$ А. Вайда, Задуми завжди цікквіші, [w:] А. Вайда, Кіно і решта світу, s. 225.

Studia Filmoznawcze, 39, 2018

(C) for this edition by CNS 
żenie umiejętność polskiego artysty tworzenia nasyconej i przekonującej atmosfery czasów rozprawiania się nikczemnych z niewinnymi. Co z resztą dało się wyczuć i w filmie Danton. Nie mamy możliwości przeczytania scenariusza Sołżenicyna, ale znając twórczość tego pisarza, można przynajmniej domniemywać, o co w owym scenariuszu chodziło.

W filmie Wajdy publiczne stracenie Dantona jest poprzedzone długim posiedzeniem sądu, w którego trakcie podsądnemu dano możliwość obrony swoich praw i udowodnienia niewinności (chociaż ta zacięta bitwa była z góry rozstrzygnięta: sąd i tak ogłosił „winę” Dantona). Ale miliony represjonowanych w ZSRR, którzy jeśli nie trafili na szubienicę, to zapełniali rozrzucone po bezkresnych przestrzeniach ZSRR radzieckie obozy koncentracyjne GUŁagu (Главного управления лагерей), nie mogli nawet marzyć o czymś takim jak sąd. System karny okresu totalitaryzmu w ZSRR był na niebosiężnym poziomie „świetności”, działał tak sprawnie i efektywnie, że nie pozwalał sobie na żadną stratę czasu na procedury typu sąd, a wyrok wydawała „trójka” na podstawie śledztwa. Sprawy polityczne w większości były fabrykowane. I właśnie dlatego odsłonięcie nikczemnych praktyk i demaskacja kultu jednostki Stalina oraz prawda, która wyszła na jaw w przemówieniu Nikity Chruszczowa na XX Zjeździe KPZR, zapoczątkują czas „odwilży” i proces rehabilitacji niewinnie skazanych. W 1962 r. zostaje opublikowana opowieść Jeden dzień Iwana Denisowicza, napisana na podstawie przeżyć byłego oficera armii radzieckiej i wieloletniego więźnia łagrów - Aleksandra Sołżenicyna, która staje się sensacją. Surowa, artystycznie doskonała opowieść o GUŁagu straszną prawdą zrobiła wrażenie na wielu. Sołżenicyn nie ograniczył się do tego krótkiego utworu — uważał za swój obowiązek opowiedzieć światu o wszystkich obozach koncentracyjnych. Tak pojawiło się epokowe dzieło Archipelag GUŁag, w którym zebrał i artystycznie przetworzył fakty rzeczywistych warunków życia katorżników Workuty, Norylska, Kołymy, Kengiru. I najważniejsze — jeden z tomów mówi o niepokorności i buntach w obozach po śmierci Stalina, kiedy więźniowie wierzyli, że sytuacja w kraju się zmieni. Sołżenicyn pisze, że powstania inicjowali i organizowali byli żołnierze Ukraińskiej Armii Powstańczej, którzy mieli doświadczenie konspiracji, a przygotowanie do insurekcji rozpoczęli od rozpraw z donosicielami. Dramatyczne powstanie w Norylsku i Workucie, chociaż stłumione, przyniosło rezultaty — system niebywałego w historii ludzkości okrucieństwa nieco zelżał. Ale, jak zawsze w historii tyraństwa, przebieg powstań zależy od miejscowych urzędników. W Kengirze zbuntowani więźniowie utrzymali się prawie dwa miesiące, ale komendant obozu, nie mogąc stłumić powstania własnymi siłami, wezwał czołgi, które przyjechały na daleki kazachski step, zwaliły ogrodzenie, wtargnęły na teren obozu i spacyfikowały większość więźniów. Być może właśnie o tę tragiczną historię, dla władzy sowieckiej powszedni epizod, chodziło w scenariuszu Sołżenicyna.

Jednak Wajda nie podjął się realizacji tego projektu. To było w 1983 r., kiedy nie mógł zapomnieć o swoim kraju, w którym generał Jaruzelski wprowadził 
stan wojenny, a sytuacja polityczna nie dawała się przewidzieć. Według jego słów, gdyby podjął się realizacji tego, co mu zaproponowano w USA, drogę do ojczyzny miałby zamkniętą. A jako emigrant reżyserować nie chciał i nie planował. $Z$ tych powodów odmówił, choć scenariusz z jego autentycznością i duchem protestu odebrał bardzo pozytywnie.

Szansa pokazania ukrytej dla świata prawdy o istocie systemu radzieckiego została utracona. Ale satysfakcję przyniósł przejmujący, tragiczny epicki utwór Katyń (2007). Zagłada polskich oficerów z rąk enkawudzistów nabiera w nim cech ogólnoświatowych. W tym filmie mistrzostwo twórcy spotkało się z osobistym bólem autora. Wajda wyrósł bez ojca, bo wśród wielu ofiar systemu komunistycznego był Jakub Wajda, rozstrzelany podczas drugiej wojny światowej, ale nie w Katyniu, jak piszą źródła internetowe, lecz w Charkowie, w katowni NKWD. Motywy autobiograficzne (zwłaszcza wątek kobiety czekającej na wiadomość o mężu, który trafił do niewoli radzieckiej) łączą się z uwydatnieniem sowieckiej „równości” wszystkich — zgodnie z nią każdy, kto w jakikolwiek sposób odstawał, musiał ulec zagładzie.

W Katyniu równolegle rozwijają się dwie linie fabularne. W pierwszej żony zniewolonych oficerów czekają na wiadomości, w drugiej polscy oficerowie znoszą sowiecką niewolę. Wysokie nary w barakach obozowych, drastyczne zagęszczenie ludzi, ich żarliwe nadzieje, że zostaną wypuszczeni — to wszystko ściska za serce. Ale zamiast spełnienia ich nadziei, po niecałym roku Sowieci wszystkich wywiozą ciężarówkami nie wiadomo dokąd. Pośrodku lasu każą wysiąść i wejść do niezidentyfikowanego, mrocznego pomieszczenia. Tam na nich czekała śmierć. O tym że władza radziecka zgładziła polskich oficerów, w Polsce było wiadomo już w 1943 r. Informacja taka pojawiła się w jednej z krakowskich gazet, w której ogłoszono listy zaginionych. Tę zbrodnię odkryli hitlerowcy. Przeprowadzili ekshumację i za pomocą prasy ogłosili światu straszną prawdę ${ }^{6}$. Ale po wojnie propaganda radziecka winą za zagładę obarczyła hitlerowców. Niemcy, na których spoczywał już gigantyczny ciężar win za zbrodnie przeciwko ludzkości, nie potrafili odeprzeć tego kłamstwa. A w ZSRR ten fakt, i wiele innych komunistycznych przestępstw, przemilczano. Prawda wypłynęła dopiero po rozpadzie Związku Radzieckiego. Jednak współczesna Rosja, broniąc „honoru munduru” radzieckich organów, szukała w Polsce ludzi pomocnych w wyciszeniu skandalu.

Samej Rosji prawda Wajdowskiego filmu o tragedii katyńskiej nie bardzo mówiąc delikatnie - się spodobała. Prowadzący program Od pierwszej osoby na jednym z kanałów telewizyjnych, demonstrując rzekomy szacunek do Mistrza, zadał mu między innymi „taktowne” pytanie, czy aby osobisty ból (spowodowany utratą ojca) nie przeszkadzał mu w obiektywnym formowaniu świata przedstawio-

${ }^{6} \mathrm{~W}$ czasie gdy powstawał film, w Polsce ukazał się album poświęcony ofiarom Katynia, zawierający fotografie rzeczy, na podstawie których identyfikowano ofiary (guziki, sprzączki itp.). 
nego, a więc historycznego, filmu. W odpowiedzi Wajda powiedział, że Katyń to nie tylko przestępstwo, lecz także kłamstwo. Ujrzawszy ów słynny numer krakowskiej gazety z listą ofiar katyńskich, Polacy nie stracili wiary. Przecież podczas pierwszej wojny światowej jeńców nie rozstrzeliwano, przecież oficerowie w Katyniu nie byli uzbrojeni, nie stawiali oporu. Istniała wszakże cywilizowana praktyka wymiany jeńców. Dlatego w Polsce ludzie nie mogli uwierzyć, że jeńców wojskowych rozstrzelano, a matka Wajdy do samej śmierci w 1950 r. pisała i wysyłała telegramy do różnych krajów, licząc na odnalezienie swojego męża. Ludzie nie mogli wyrzec się swej wiary, swoich wyobrażeń. Wajda wykonał swoje zadanie — pokazał nie tylko zbrodnię, lecz także haniebne kłamstwo.

Trzeba przyznać, że reżyseria tego bezkompromisowego filmu, który odkrywa potworne praktyki sowieckiej wierchuszki i jej opryczników enkawudzistów, wymagała niemałej odwagi. Precyzyjnie i przekonująco wypowiedziana prawda współczesnemu widzowi umożliwia obecność w tych strasznych totalitarnych czasach „splądrowanego stulecia”. A finałowa scena rozstrzelania, która stanowczo nie jest dla ludzi o słabych nerwach, siłą reżyserskiej realizacji przypomina apogeum zezwierzęcenia - „noc długich noży” w filmie Luchino Viscontiego Zmierzch bogów. I w pierwszym, i drugim przypadku uśmierca się mnóstwo ludzi, którzy nie mogą się bronić. I jest to dowód jeszcze niezbadanej masowej psychozy, którą zarażone były hitlerowskie Niemcy i stalinowski ZSRR.

Kiedy w ramach swoich uniwersyteckich zajęć filmoznawczych, wygłaszając wykład o polskim kinie i Andrzeju Wajdzie, zapytałam studentów, czy rozumieją słowo „Katyń” i to, co się pod nim kryje, to nikt z pięćdziesięciu osób zgromadzonych w sali nie wiedział. Widocznie w ramach szkolnych programów historii zbrodnia ta nie jest omawiana. Zabójstwo jeńców, którzy nie stawiali oporu i dobrowolnie oddali się w niewolę, jest wielką zbrodnią. Ale to tylko jedna z wielu zbrodni w ZSRR przeciwko ludzkości. Pozostałe nie ujrzały jeszcze światła dziennego. Jednak film taki jak Katyń nie pozwoli o nich zapomnieć. Praca Wajdy to nieoceniony wkład w skarbnicę ludzkiej pamięci. Mam nadzieję, że i moi studenci obejrzą ten film. Szkoda, że w kinie ukraińskim do tej pory nie znalazł się reżyser, który by z takim kunsztem opowiadał o tragedii swojego narodu. Na Ukrainie jest mnóstwo filmów dokumentalnych o Wielkim Głodzie (przede wszystkim Żywy Sergieja Bukowskiego), obrazów o represji, dokumentalnych esejów o inteligencji, która stała się ofiarą bolszewickiego terroru, jednakże nie mają one takiej siły oddziaływania, takiego artystycznego wyrazu jak filmy Wajdy. Żeby zrealizować dzieło z takim estetyczno-ideowym rozmachem, oprócz pomysłu i maestrii reżyserskiej trzeba też mieć bogate doświadczenie życiowe i artystyczne, a także niebanalną zdolność pojmowania rzeczy ludzkich — psychologicznych, moralnych, społecznych, politycznych - czyli po prostu mądrość.

Istnieje jeszcze jedno dzieło Mistrza wpisujące się obszar naszych badań. Film Bez znieczulenia, który ukazał się w 1978 r., słusznie jest zaliczany do „kina moral- 
nego niepokoju", mimo że pozostaje w cieniu bardziej sławnego obrazu, jakim jest polityczny fresk Człowiek z marmuru.

Kameralny psychologiczny dramat Bez znieczulenia nieprzypadkowo pojawił się w czasach komunistycznego ucisku, kiedy polscy reżyserzy filmowi podjęli problematykę degradacji ludzi, spowodowanej pułapkami, miazmatami socjalizmu panującego w powojennej Polsce. W filmie kładzie się akcent nie na sytuację społeczną, lecz przede wszystkim na jednostkowo pojmowane człowieczeństwo, chociaż jedno i drugie, rzecz jasna, są wzajemnie powiązane.

Bohater filmu — reporter zagraniczny Jerzy Michałowski — wraca z kolejnej delegacji, żona przez adwokata przekazuje mu wiadomość, że odchodzi od niego i składa pozew o rozwód. Widz od samego początku staje przed pytaniem, na które nie ma logicznej odpowiedzi: dlaczego żona nie chciała spotkać się z mężem i wyjaśnić mu przyczyny zainicjowanego przez nią rozstania? Tym bardziej że rodzina - jak się wydaje - należy do udanych i szczęśliwych, a małżonkowie mają dwójkę cudownych dzieci. Argument, że kobieta krzywdzi męża, gdyż zabiera ojca swoim dzieciom (nie pozwala dzieciom z nim się spotykać), do niej nie przemawia. O przyczynie rozwodu bohater ma się dowiedzieć sam, a razem z nim widz. Powodem być może jest zazdrość żony o sukcesy męża. Być może to odczuwana przez kobietę samotność była przyczyną tej decyzji, przecież mąż był ciągle w delegacjach. Stał się dla niej nie tylko obojętny, lecz wręcz wrogiem, którego trzeba zniszczyć. Kobieta już jest z innym mężczyzną. To współpracownik jej męża - nieudacznik, który widzi w Michałowskim rywala przeszkadzającego mu w zrobieniu kariery. Uwodziciel nie tylko wykorzystuje żonę kolegi jako narzędzie do pozbycia się konkurenta i zrujnowania rodziny, krytykuje go między innymi za jego pracę naukową. Wszystko dlatego, że Jerzy stał się człowiekiem niewygodnym dla partyjnego kierownictwa, które „załatwiło” go bezsłownym prześladowaniem. Kolejną traumą było wyrzucenie go z pracy, w której nikt za nim się nie wstawił, chociaż wydawało się, że miał wokół siebie przychylne i wpływowe osoby.

Czy człowiek mógł się podnieść, otrzymawszy taki cios? Byłoby to możliwe, gdyby nie rodzinna katastrofa. Rodzina była dla niego jak powietrze: nie zauważasz go, gdy ono jest, ale gdy go brakuje - człowiek umiera. Michałowski być może nawet nie podejrzewał, jak bardzo był do swojej rodziny przywiązany. Wiadomość, że żona wyprowadziła się do swojej matki, odmawiając spotkania, a nawet rozmowy przez telefon, wyprowadziła go z równowagi tak, że zabrakło mu sił, by otrząsnąć się z tego ciosu. Skoro Wajda nie odsyła nas do przeszłości, nie proponuje flashbacków, to znowu pojawiają się przypuszczenia, czy bohater nie oczekiwał takiego zachowania żony, czy może po prostu jej nie znał. Nie znał jej, dlatego nie oczekiwał. Dla widza, ale nie dla protagonisty, jej podstępność jest zauważalna. Michałowski próbuje walczyć o swoją rodzinę, szuka sposobu na porozumienie, prosi żonę przez jej koleżankę o przebaczenie. Spotkanie, do którego się tak przygotowywał, które dawało nadzieję na porozumienie, odbyło się tak, że żona odeszła bez pożegnania. 
Ta przejmująca scena, jak też scena rozprawy sądowej świadczą o jej całkowitym posłuszeństwie wobec niewiadomych sił: wykonuje jakby rozkaz niszczący męża. On natomiast nie szuka ratunku, nie szuka innego wyjścia, fatalistycznie poddając się losowi.

W przypadku tej historii happy end jest niemożliwy, do akcji wkraczają siły fatum: starsza córka studentka przyszła rano do jego mieszkania w chwili, gdy jakaś nieznajoma dziewczyna wychodziła z łazienki - zachowanie ojca oburzyło córkę. Z pewnością nie wie ona, że owa młoda nieznajoma studentka to swoisty anioł stróż Jerzego, czuwający, aby ten niczego sobie nie zrobił. Przeczucia „anioła” się potwierdziły - kiedy wyszła załatwić swoje sprawy, w mieszkaniu doszło do wybuchu gazu. Widz wraz z bohaterami filmu widzi, jak ratownicy pogotowia wynoszą poparzonego Michałowskiego. Nieszczęśliwy wypadek bardzo przypomina samobójstwo. Życie bez rodziny i ulubionej pracy to jak operacja bez narkozy, ból przeżytego cierpienia sprawia, że życie traci sens.

Ta tragiczna historia zbudowana jest $\mathrm{z}$ dwu oddzielnie i naprzemiennie ułożonych linii życiowych dwojga ludzi. Reżyser stopniowo zagęszcza atmosferę, widz fizycznie odczuwa, że ukazana sytuacja jest beznadziejna, bez wyjścia. Czego zabrakło tym dwóm osobom? Dlaczego życie człowieka sukcesu zostało doszczętnie zrujnowane? Czy to efekt ontologicznej skłonności człowieka do destrukcji, czy niemożność ochronienia się przed manipulacją?

Gdy przedmiotem artystycznego przedstawienia w dziele fabularnym stają się konfliktowe sytuacje w życiu prywatnym bohaterów, autor zazwyczaj trzyma którąś ze stron. Wajda, zagłębiwszy się w relacje między małżonkami, pozostaje bezstronny, a przecież mimo to widz współczuje przede wszystkim głównemu bohaterowi. Charakterystyczne, że bohater nie szuka czegoś, co go znieczuli (może nie bez powodu na początku filmu prosi, by wyrwać mu ząb bez znieczulenia), przyjmuje wszystkie ciosy, tracąc przy tym nadzieję. Mężczyzna nie szuka przyczyn kryzysu rodzinnego, szuka natomiast pojednania i ponosi klęskę. Mistrzostwo reżysera przejawia się w wywołaniu u odbiorcy bólu i głębokiego współczucia wobec bezbronnego człowieka. Jeżeli chodzi zaś o jego żonę, efekt jest odwrotny, jej chłodny stosunek do wszystkich, w tym własnych dzieci, powoduje, że jest ona postacią nieciekawą, jakby nakręcaną mechaniczną lalką.

Wajda pokazał zależność między intymnym światem człowieka a ogólną atmosferą w państwie, w którym pielęgnuje się zawiść, nienawiść i pogardę. Na przykładzie jednej rodziny reżyser postawił diagnozę całemu społeczeństwu, gdyż, jak pisali krytycy, na arenę życia społecznego coraz częściej zaczęły przenikać bezwstydne, cyniczne oszustwa ze sfery polityki i ekonomii, których grunt tworzył patologiczny układ monopartiokracji.

Powidoki, ostatni film Wajdy, jest w konwencji i duchu tragiczny równie jak Bez znieczulenia. Władysław Strzemiński, malarz awangardy, wykładowca krakowskiej Akademii Sztuk Pięknych, podobnie jak Jerzy Michałowski przejdzie przez 
bramy piekła. Jego życie wyglądałoby inaczej, gdyby zgodził się na kompromis z władzą i przejawił wobec niej przychylność. Był to jednak człowiek bezkompromisowy i odważny — dopóki istniała możliwość, publicznie wyjaśniał działaczom partyjnym, dlaczego nie przyjmuje socrealizmu w sztuce. Artysta wobec władzy totalitarnej. Malarz jako ofiara ideologicznego terroru. Twórca, który życie oddał — dosłownie - Sztuce. Władza w osobie prokuratorów i służby bezpieczeństwa pozbawia go wszystkiego - wiary, środków do życia, rozdziela go z córką, jednakże on pozostaje niezłomny. Postać Strzemińskiego należy bez dwóch zdań do najlepszych ról Bogusława Lindy. W bezwzględnym konflikcie między władzą a Strzemińskim w Powidokach Ukraińcy poznają historię sztuki „rozstrzelanego odrodzenia”, a w szczególności historię reżysera teatralnego, awangardzisty Łesia Kurbasa, a także dramaturga Mikoły Kulisza, których tak samo stopniowo i metodycznie pozbawiano możliwości tworzenia, później aresztowano i zesłano na Wyspy Sołowieckie, a następnie rozstrzelano w $1937 \mathrm{r}^{7}$ Można więc powiedzieć, że film Wajdy nie dotyczy tylko jednego człowieka, lecz jest o wszystkich artystach, którzy żyli, tworzyli i zginęli w niezliczonych obozach koncentracyjnych ZSRR.

W Powidokach i w Dyrygencie (1979) Wajda oddał hołd Sztuce. Sztuce z dużej litery, pokazując jej siłę, a na jej tle - nikczemność czynowników, którzy jej nie rozumieją i którzy chcą czy to zniszczyć niepokornego artystę, czy to „wtargnąć” do jego twórczości ze swoimi merkantylnymi racjami interpretacyjnymi. Wajda przypomina, że ani polityczna, ani administracyjna prawość nie powinny naruszać harmonii sztuki. Sztuka nie znosi bezdusznej i nieprzemyślanej interwencji, wtrącanie się w nią jest zgubne. Obraz znanego na świecie dyrygenta Johna Lasockiego, stworzony przez Johna Gielguda, to harmonijne połączenie artystycznego profesjonalizmu i niezbędnych dla wspólnoty muzyków cech ludzkich, zwłaszcza opanowania i pokory. Właśnie przez napełnienie ludzką i zawodową godnością dyrygenci tworzą prawdziwą muzykę - V Symfonię Beethovena, która brzmi w trakcie filmu $\mathrm{i}$ jest jednym $\mathrm{z}$ jego bohaterów, kontrastującym $\mathrm{z}$ bezsensowną i nieuczciwą gadaniną czynowników. I jeszcze jeden bohater — sceptyczny Adam, którego zagrał Andrzej Seweryn. Jest on ofiarą własnych ambicji i zazdrości o talent, o prawdziwą sztukę - ideał dla niego nieosiągalny. Dyrygent mówi o ludziach, którzy ze względu na ich małostkowość i nieopanowanie nie powinni zajmować się muzyką symfoniczną, a tym bardziej kierować orkiestrą. Dzięki skontrastowaniu maestra

7 „Rozstrzelane odrodzenie” (ukr. Розстріляне відродження) — termin stosowany na określenie pokolenia ukraińskich artystów i naukowców, działających w latach 20. i początku lat 30. XX w. na terenie Ukraińskiej Socjalistycznej Republiki Radzieckiej. Większość przedstawicieli tego pokolenia została aresztowana i zamordowana przez NKWD w latach 30. XX w. Termin ten został zaproponowany przez emigracyjnego ukraińskiego literaturoznawcę Jurija Ławrinenkę, który użył go jako tytułu almanachu ukraińskiej prozy i poezji z lat 1917-1933, wydanego na emigracji — w Paryżu w 1959 r. przez Instytut Literacki, pod patronatem Jerzego Giedroycia i „Kultury”, https://pl.wikipedia.org/wiki/ Rozstrzelane_odrodzenie [przyp. red.]. 
Lasockiego z młodym zakompleksionym Adamem Wajda pokazuje, że sztuka nie znosi automatycznego i bezdusznego podejścia, pokazuje, że twórczość to delikatna, żywa materia.

Wajda należy do tych reżyserów, którzy podobnie jak François Truffaut i Luchino Visconti opowiadają się za ochroną klasycznej sztuki przed wulgaryzacją i surogatami. Do opisania stylu reżysera możemy użyć terminu „magiczny realizm” lub też posłużyć się muzyczną paralelą: filmy takie, jak Ziemia obiecana, Danton, Pan Tadeusz, Katyń naśladują dźwięki potężnej orkiestry symfonicznej, która wykonuje skomplikowany utwór polifoniczny. Natomiast filmy o życiu prywatnym (Bez znieczulenia, Dyrygent) to muzyka kameralna, pełna niepokoju, w niej opiewa się uduchowioną osobowość i jej wytrzymałość w konflikcie z siłami zła. W obu przypadkach widoczna jest działalność grupy ludzi, wychodzącej poza własne granice, która daje szeroki obraz stosunków międzyludzkich i społecznego niepowodzenia.

Oprócz tych muzycznych paralel należałoby przeprowadzić i paralelę kinematograficzną. W tym przypadku z Ingmarem Bergmanem. Podobnie jak szwedzki reżyser Wajda niejednokrotnie był współautorem scenariuszy swoich filmów, a także łączył w swojej twórczości różne sfery sztuki: kino, telewizję, teatr, co świadczyło nie tylko o wielkości jego talentu, lecz także o wielkim zapasie weny twórczej. Wajdę, tak jak Bergmana, ciekawił przede wszystkim człowiek, jego odczucia moralne i los w złożonych warunkach politycznych i społecznych. Jednak między tymi dwoma reżyserami istnieją widoczne odmienności. Pierwsza to doświadczenia życiowe oraz środowiska, w których żyli. Bergman często pokazuje dramaty moralne, którymi były przeważnie konflikty toczące się, by tak rzec — na froncie rodzinnym, motywowane nie całkiem szczęśliwym życiem prywatnym samego Bergmana, co szczególnie dawało się zauważyć w stosunkach reżysera z ojcem, o czym pisał w swoich pamiętnikach. Znacznie tragiczniejsze były doświadczenia Wajdy, który przez długi czas mieszkał w niewielkim - w stosunku do imperium radzieckiego — państwie, widząc niesprawiedliwość i obłudę przyniesione przez władzę radziecką. Dosięgnął go również brak ojcowskiej miłości i ból utraty ukochanej osoby. W zideologizowanej pedagogice socjalistycznej bynajmniej nie akcentowano potrzeby wpajania szacunku czy miłości do ojca, a tym bardziej gdy ojcem był żołnierz Armii Krajowej, identyfikowanej przez władze z najgorszym złem. Ukraińska poetka szlacheckiego rodu Łesia Ukrainka nie dożyła czasów bolszewickich. Ale jej matka, pisarka Ołena Pcziłka, dożyła. Za prawdziwy patriotyzm była aresztowana przez czekistów, tak jak inni ukraińscy inteligenci. Ci, którzy uwierzyli w „sprawiedliwy" ład lub udawali, że uwierzyli, byli tolerowani (jak Ołeksandr Dowżenko), takich uważano za towarzyszy, którzy „są z nami”, ale „nasi” nie są.

$\mathrm{Na}$ koniec chciałabym wspomnieć o znaczeniu filmów Andrzeja Wajdy dla nas, Ukraińców. W czasach radzieckich jego filmy — Popiót $i$ diament, Wszystko na sprzedaż, Brzezina, Ziemia obiecana — weszły do kin i widzowie odbierali je, podobnie jak filmy Jerzego Hofmana, z wielkim zainteresowaniem, choć doskona- 
le wiedzieli, że większość utworów Wajdy nie została „wpuszczona” na Ukrainę. Władza radziecka cenzurowała kino zagraniczne. Było ono dostępne w postaci nośników VHS i w kinoteatrach dopiero w czasach niezależnej Ukrainy. Możliwość zaznajomienia się z twórczością Wajdy stała się większa dzięki Instytutowi Polskiemu w Kijowie, który promował jego starsze filmy oraz organizował premiery najnowszych w najlepszych salach kinowych Ukrainy. Osobiście uczestniczyłam w premierze Pana Tadeusza w kinie Budynok oraz filmu Katyń w kinie Ukraina. Podczas seansu prezydent Ukrainy Wiktor Juszczenko nagrodził Wajdę Orderem Jarosława Mądrego. W przepełnionych salach kinowych odbyły się również premiery kolejnych filmów Mistrza - Wałęsa. Człowiek z nadziei i Powidoki. Ostatnio, już po jego odejściu, pod koniec października 2016 r., w trakcie otwarcia Międzynarodowego Festiwalu Filmowego „Młodość” sala uczciła pamięć Mistrza minutą ciszy.

W ukraińskim przekładzie wyszły dwie książki Andrzeja Wajdy. Druga z nich — Kino i reszta świata — ukazała się w 2004 r. i stała się bestsellerem. Mimo że na Ukrainie nie prowadzi się badań nad jego twórczością, to należy zakładać, że takie w najbliższym czasie się pojawią. Czasopismo „Kino-Teatr” przy wsparciu Instytutu Polskiego w Kijowie opublikowało wywiad po premierze filmu Wałesa. Człowiek z nadziei, w którym o swoim reżyserze wypowiedział się Andrzej Seweryn.

My, Ukraińcy, pamiętamy jego wstawiennictwo za Ukrainą, jego apel do Parlamentu Europejskiego o wsparcie Euromajdanu, jego pomoc dla utalentowanych studentów z Ukrainy, którzy uczyli się w jego szkole. On nadal żyje w swoich wybitnych filmach, które pokazując brutalność świata, uczą miłości i sławią walkę o sprawiedliwość.

Pod koniec listopada 2014 r. miałam możliwość spotkania Andrzeja Wajdy i Krystyny Zachwatowicz jako członek nielicznej delegacji filmowców i dziennikarzy zapoznających się z kinematografią Polski. Szlachetność, a jednocześnie głębokie człowieczeństwo, skromność, niepospolitość to cechy Reżysera, których nie można było nie zauważyć. Zwłaszcza że dzisiaj są one tak rzadko spotykane. Mistrz bardzo szczerze mówił o Ukrainie, która nie uległa wpływom Moskwy i za wysoką ceną wypracowała sobie realną, a nie fikcyjną niezależność. Wsparcie moralne uznanego artysty w takiej chwili ocenia się bardzo wysoko.

Reżyser każdemu wręczył album wraz z płytą filmu Wałęsa. Człowiek z nadziei, z dedykacją, co było dla nas rzeczowym symbolem przyjaźni z człowiekiem wielkiego serca i wzorem do naśladowania człowieka nieustannie walczącego o swoje ideały i pielęgnującego miłość do własnej ojczyzny. 


\title{
NOT CHANGING LOOKS. PRESENTATION OF CRUELTY AND EVIL IN THE FILMS OF ANDRZEJ WAJDA
}

\begin{abstract}
Summary
Among Andrzej Wajda's legacy, the image of the totalitarian regime and its repercussions for people, countries, and humanity holds a significant place. Films of Andrzej Wajda, who was a liaison officer in the anti-Hitler Polish underground, are a kind of chronicle of the survivors of twentieth century. The article is dedicated to study the various forms of evil and its effects on real people. The study is applicable for our time because the world again deals with the recidivism of evil which the Soviet government spread in its own country and beyond its own borders. In the USRR, the perception of Andrzej Wajda's films was dependent on the political play in action: when the relations between two countries were friendly, he received awards, however after the Solidarity was established, no one ever mentioned Wajda. The epic work Danton, about the French revolution, made in France during times difficult for Poland because of the martial law imposed on Poland, reveals the effects of revolution that paradoxically destroyed its most dedicated revolutionists, including Danton. Wajda's refusal to American producers to direct a motion picture based on a screen play of Aleksander Slozenicyn had serious reasons, primarily commitment to his homeland. He made up for the missed opportunity to show Stalin's evil empire when he shot the film Katyń. This word echoes deep tragedy in the heart of every Pole and the director succeeded in portraying the cruelty of mechanism of punishment in totalitarian USRR. The second most important aspect was the discovery of the lies of this regime, which tried to place the responsibility for the execution of Polish officers on the Nazis. After a premiere of Katyń in Ukraine, Andrzej Wajda was awarded the medal of Jaroslaw Madry. The article also includes the theme of influence of Fyodor Dostoyevsky's novels on Andrzej Wajda's work — the director not only used Dostoyevsky's work for his filmmaking and staging, but as well he was inspired by Dostoyevsky's deep analysis of dangerous social phenomena and the courage in discovering the evil. In Wajda's films, which belongs to the so-called "cinema of moral unrest", the tragic fate of a talented journalist Jerzy Michalowski, the hero of film Bez znieczulenia who personalizes the characteristics of a professional and a good man, simply horrifies. In his last film Powidoki, the director masterfully shows circles of hell survived by avant-garde artist Wladyslaw Strzeminski, the lecturer of Fine Arts Academy. All the films mentioned above are deemed necessary warning for future generations, they cannot put up with the aggression — on a political and private levels. Wajda's lessons are universal, timeless, and everlasting, like an eternal battle of good against evil.
\end{abstract}

Na język angielski przełożył Kordian Bobowski

Studia Filmoznawcze, 39, 2018

(C) for this edition by CNS 